Available online at GSC Online Press Directory

GSC Biological and Pharmaceutical Sciences

e-ISSN: 2581-3250, CODEN (USA): GBPSC2

Journal homepage: https://www.gsconlinepress.com/journals/gscbps

(REVIEW ARTICLE)

\title{
Diabetic foot infection and its management: A review
}

\author{
Anette Paulson*, Krishna Kumar K, Panayappan L and Leo Mathew \\ Department of Pharmacy Practice, St. James College of Pharmaceutical Sciences, Chalakudy, Kerala.
}

Publication history: Received on 24 May 2018; revised on 13 June 2018; accepted on 14 June 2018

Article DOI: https://doi.org/10.30574/gscbps.2018.4.1.0041

\begin{abstract}
Diabetic foot infections are common in patients with diabetes which leads to hospitalization and it is the most frequent cause of non-traumatic lower extremity amputation. Diagnosis of foot infections based on clinical signs and symptoms of inflammation. Infected lesion culturing discloses the pathogen and their susceptibilities. The predominant pathogen responsible for infection is gram-positive cocci, especially Staphylococci and also Streptococci. Gram-negative bacilli and anaerobes are mainly found in chronic or previously treated wounds. The infected wounds require antibiotic therapy, the agents, and duration of treatment are predicted based in the severity of infection and initial management of diabetic foot infection should do by empirical therapy which based on the susceptibility data. Preventive measures to control diabetic foot infections are patient education on foot care, glycemic control, use of prescription footwear, intensive care from a podiatrist, and evaluation of surgical interventions indicated. This article explains about Pathophysiology classification, assessing the severity and treatment of diabetic foot infections.
\end{abstract}

Keywords: Diabetic foot infection (DFI); Diabetes; Infection

\section{Introduction}

A diabetic foot infection (DFIs) is a syndrome characterized by local findings of inflammation or purulence occurring at the site below the malleoli in a person with diabetes. Foot infections in diabetic patients usually start with skin ulceration. Peripheral neuropathy, impaired immunity and peripheral arterial disease are the major reason for DFIs. Gram-positive bacteria such as Staphylococcus aureus and beta-hemolytic Streptococci are pathogen isolated from mild and moderate infections. In case of severe and chronic infections are often polymicrobial. Pain, edema, and purulent drainage, anorexia, vomiting, fever and worsening of glycemic control are the signs and symptoms of infection. The diabetic foot infections treatment should done by proper selection of antibiotic therapy and wound care. Initial empirical therapy is done which is based on susceptibility data. It should focus on gram-positive cocciand it is sufficient for mild and moderate infection. Broad spectrum therapy is required in severe diabetic foot infections [1]. The objective of this review is to describe the pathophysiology, classification, assessing the severity and treatment of diabetic foot infections.

\section{Pathophysiology}

The infections usually occur in the site of skin trauma or ulceration. Major predisposing factor for DFI is neuropathy, vasculopathy, and immunopathy. Peripheral neuropathy occurs early in the pathogenesis of diabetic foot complications and is considered the most prominent risk factor for diabetic foot ulcers. Peripheral neuropathy which leading to skin breaks and ulcerations, which then become colonized with skin flora and ultimately infected. Motor neuropathy causes muscle weakness and intrinsic muscle-imbalance leading to digital deformities such as hammered or clawed toes and

\footnotetext{
${ }^{*}$ Corresponding author

E-mail address: stjamespharmacyproject@gmail.com
}

Copyright (C) 2018 Author(s) retain the copyright of this article. This article is published under the terms of the Creative Commons Attribution Liscense 4.0. 
results in elevated plantar pressure due to metatarsophalangeal joint instability. Autonomic dysfunction cause changes in microvascular blood flow and arteriolar-venous shunting, diminishing the effectiveness of perfusion and elevating skin temperatures. With the loss sweat gland function, the diabetic foot becomes dry and keratinized which cracks and fissures more easily, leading to a portal for infection [2].

Foot ischemia, related to peripheral vascular disease, is common in patients with a DFI but rarely the primary cause of foot wounds, the presence of limb ischemia increases the risk of a wound becoming infected.

In immunopathy have the impairment in the host defenses includes defects in leukocyte function and morphologic changes to macrophages. Bagdade et al., demonstrated that leukocyte phagocytosis was significantly decreased in patients with poorly controlled diabetes, and improvement of microbicidal rates was directly related to the correction of hyperglycemia. Diabetic patients poorly tolerate the infection adversely affects diabetic control. This cycle causes uncontrolled hyperglycemia, further affecting the host's response to infection [3].

\section{Microbiology of diabetic foot infections}

Aerobic gram-positive cocci such as Staphylococcus aureus and the Beta-hemolytic Streptococci are the most common pathogens that found in acute infection [4].Serious infections in hospitalized patients are caused by aerobes and anaerobes [5]. Chronic infections are caused by Enterococci, various Enterobacteriaceae obligate anaerobes, Pseudomonas aeruginosa, and sometimes, other Non-fermentative gram-negative rods [6]. Gram-negative bacilli, mainly of Enterobacteriaceae, are found in patients with chronic or previously treated infections. Pseudomonas species found in wounds that have been soaked or treated with wet dressings or hydrotherapy. Enterococci are obtained from patients who have previously received a cephalosporin. Obligate anaerobic species are isolated from wounds with ischemic necrosis or that involve deep tissues. Antibiotic-resistant organisms, especially methicillin resistant $S$. aureus, are found from patients who have previously received antibiotic therapy; they are often acquired during the previous hospitalization [7].

\section{Risk factors for diabetic foot infections}

The risk factors for diabetic foot infection (DFI) are wounds that penetrated to the bone, wounds with a duration $>30$ days, recurrent wounds, wounds with traumatic etiology and the presence of peripheral arterial disease. Neuropathy and history of the previous amputation is significant risk factors for infection. The risk of infection more in walking barefoot, the risk of hospitalization and amputation was greater in patients with DFI compared to those without [8].

\section{Classification of diabetic foot infection}

Several classification systems have been developed for the assessment of DFI. The Infectious Disease Society of America (IDSA) and International Working Group on Diabetic Foot (IWGDF) have developed guidelines which classify DFI, and thereby guide for proper therapy. The classifications include four progressive levels of infection (Table 1).

Table 1 Classification of the diabetic foot infection [9]

\begin{tabular}{ll}
\hline Clinical manifestation of infection & $\begin{array}{l}\text { IWGDF } \\
\text { classification }\end{array}$ \\
\hline $\begin{array}{l}\text { No systemic or local signs of infection. } \\
\text { Local infection involving only the skin or subcutaneous tissue ( without involvement of } \\
\text { deeper tissues and without signs of a systemic inflammatory syndrome); any erythema } \\
\text { present extends } 0.5 \text { to } \leq 2 \mathrm{~cm} \text { around the wound }\end{array}$ & 2 (Mild infection) \\
$\begin{array}{l}\text { Local infection with erythema }>2 \text { cm around the wound, or involving structures deeper } \\
\text { than skin and subcutaneous tissues(e.g. Abcess, osteomyelitis, septicarthritis, fasiitis) }\end{array}$ & 3 (Moderate infection) \\
$\begin{array}{l}\text { and no sign of a systemic inflammatory response syndrome. } \\
\text { Local infection with signs of a systemic inflammatory response syndrome. }\end{array}$ & 4 (Severe infection) \\
\hline
\end{tabular}




\section{Diagnosis and clinical presentation of diabetic foot infection}

Diagnosing a DFI begins with the clinical suspicion through a comprehensive history and physical examination, validated by complete laboratory evaluation, microbiology assessment, and diagnostic imaging. Patients present with complaints ranging from local to systemic signs of infections. Local signs of infections are pain/tenderness, erythema, edema, purulent drainage. Systemic sign of infection are anorexia, nausea, vomiting, fever, chills, night sweats, and change in mental status and worsening of glycemic control. Almost about two-thirds of patients with a diabetic foot infection have the peripheral vascular disease, and patients lost their protective sensation. Infections most affect the forefoot, especially the toes and metatarsal heads, particularly on the plantar surface. Severe deep infection indicated by the presence of systemic signs or infection [10].

Laboratory values are essential in DFI. DFI patients have increased WBC, erythrocyte sedimentation rate (ESR) and Creactive protein level (CRP). These are markers of inflammation which are elevated in response to inflammation and infections. Culture and sensitivity test is required for the selection of proper antibiotics. Plain film radiography, magnetic resonance imaging (MRI) are used to determine the osteomyelitis and also bone scans, such as the white blood cell labeled indium-111, Technetium-99m HMPAO, and Sulfur Colloid Marrow Scan [11].

\section{Assessing severity of infection}

Assessing severity of infection is important in DFIs which influence the proper antibiotic selection, the route of administration, and also help in determining the need for hospitalization. Assessing severity of infection also help in determining the potential necessity, timing of surgery and necessity of amputation [12].Clinical features help to define the severity of infection (Table 2)

Table 2 Clinical characteristics that help to define the severity of an infection [13]

\begin{tabular}{|c|c|c|}
\hline Feature & Mild infection & Severe infection \\
\hline Presentation & Slowly progressive & Acute or rapidly progressive \\
\hline Ulceration & Involves only skin & Penetrates to subcutaneous tissues \\
\hline Tissues involved & Epidermis, dermis & Fascia, muscle, joint, bone \\
\hline Cellulites & $\begin{array}{l}\text { Minimal } \quad(<2 \quad \mathrm{~cm} \\
\text { around ulcer rim })\end{array}$ & Extensive, or distant from ulceration \\
\hline Local signs & Limited inflammation & $\begin{array}{l}\text { Severe inflammation, crepitus, bullae, } \\
\text { necrosis or gangrene }\end{array}$ \\
\hline Systemic signs & None or minimal & $\begin{array}{l}\text { Fever, chills, hypotension, confusion, } \\
\text { volume depletion, leucocytosis }\end{array}$ \\
\hline Metabolic control & $\begin{array}{l}\text { Mildly abnormal } \\
\text { (hyperglycemia) }\end{array}$ & $\begin{array}{l}\text { Severe hyperglycemia, acidosis, } \\
\text { azotemia, electrolyte abnormalities }\end{array}$ \\
\hline Foot vasculature & $\begin{array}{l}\text { Minimally impaired } \\
\text { (normal/reduced } \\
\text { pulses) }\end{array}$ & $\begin{array}{l}\text { Absent pulses, reduced ankle or toe } \\
\text { blood pressure }\end{array}$ \\
\hline Complicating features & $\begin{array}{l}\text { None or minimal } \\
\text { (callus, ulcer) }\end{array}$ & $\begin{array}{l}\text { Eschar, foreign body, puncture wound, } \\
\text { abscess, marked edema, implanted } \\
\text { metalwork or other prostheses }\end{array}$ \\
\hline
\end{tabular}

\section{Treatment of diabetic foot infection}

\subsection{Surgery, podiatry and revascularization}

Moderate to severe DFI require surgical management it includes aggressive incision, drainage, and debridement of nonviable soft tissue and bone. The severity of amputation increased with severity of the infection. Minor amputation is the removal of a portion of foot distal to the ankle joint and major amputation is proximal to ankle joint. Early surgical 
management of DFI may reduce the necessity of major amputations. Emergency surgery needed for severe infection in an ischemic limb, necrotizing fasciitis, gas gangrene, and an infection associated with compartment syndrome [14].

Podiatric care is aimed at debridement of callus and necrotic tissue, caring for nails, treatment of blisters and selecting proper footwear.

Vascular assessment is required in patients with a diabetic foot wound. Patients with clinically compromising arterial insufficiency of the foot require revascularization, if feasible. This may be done by either endovascular or open methods [15].

\subsection{Antimicrobial therapy}

Antibiotic therapy is required for treating DFI. Initial antibiotic therapy selected empirically, and it is based on the presenting clinical features, assessment of infection severity and by knowledge of antibiotic resistance pattern. Antibiotic coverage should include S.aureus for the treatment of mild infections. If the prevalence of methicillinresistance among $S$. aureus isolates is high or if the infection is more than mild, anti-MRSA therapy is needed. The antibiotics selected for severe or previously treated DFI should include extended coverage for gram-negative bacilli and Enterococcus species.

Anti-anaerobic therapy is essential for gangrenous and foul-smelling wounds. Cost of therapy, potential side effects, bioavailability, frequency and route of administration are important in selection of the treatment regimen. Initial parenteral and broad-spectrum therapy is needed for severe infections. Reassessing of patient should do after 24 to 72 hours after initiating empirical antibiotic therapy. Evaluate the response and modify the antibiotic regimen if indicated [16].

Table 3 Antibiotic regimen based on the recent IDSA guidelines [17]

\begin{tabular}{|c|c|c|c|c|}
\hline $\begin{array}{l}\text { Severity } \\
\text { infection }\end{array}$ & Expected pathogens & Potential antibiotic agents & $\begin{array}{l}\text { Administration } \\
\text { route }\end{array}$ & $\begin{array}{l}\text { Duration } \\
\text { treatment }\end{array}$ \\
\hline Mild & $\begin{array}{l}\text { Staphylococcus aureus } \\
\text { Streptococci }\end{array}$ & $\begin{array}{l}\text { Cephalosporin's Clindamycin, } \\
\text { Co-amoxiclav }\end{array}$ & Oral & 1-2 week \\
\hline Moderate & $\begin{array}{l}\text { Similar to those for mild } \\
\text { infections, } \\
\text { Enterobacteriaceae }\end{array}$ & $\begin{array}{l}\text { Co-amoxiclav, } \\
\text { combination of quinolone+ } \\
\text { clindamycin }\end{array}$ & $\begin{array}{l}\text { Oral } \\
\text { parenteral } \\
\text { start) }\end{array}$ & 2-3 weeks \\
\hline Severe & $\begin{array}{l}\text { All pathogens, may be } \\
\text { anaerobes and } \\
\text { Pseudomonas aeruginosa }\end{array}$ & $\begin{array}{l}\text { Piperacillin-tazobactum, } \\
\text { cefepime, carbapenem }\end{array}$ & $\begin{array}{l}\text { Parenteral, with } \\
\text { oral switch when } \\
\text { stable }\end{array}$ & 2-3 week \\
\hline $\begin{array}{l}\text { Recent } \mathrm{Rx} \\
\text { with } \\
\text { antibiotics }\end{array}$ & $\begin{array}{l}\text { Consider P. aeruginosa, } \\
\text { MRSA }\end{array}$ & $\begin{array}{l}\text { Piperacillin-tazobactum, } \\
\text { cefepime, carbapenem }\end{array}$ & Parenteral & 2-3 week \\
\hline Bacteremic & $\begin{array}{l}\text { Most often } S \text {. aureus but } \\
\text { others possible }\end{array}$ & $\begin{array}{l}\text { Based on culture and sensitivity } \\
\text { results }\end{array}$ & Parenteral & 2-3 week \\
\hline Osteomyelitis & $\begin{array}{l}S . \text { aureus, streptococci, } \\
\text { Enterobacteriaceae }\end{array}$ & Based on bone culture, if possible & $\begin{array}{l}\text { Oral (perhaps after } \\
\text { initial parenteral) }\end{array}$ & $\begin{array}{l}4-6 \text { week } \\
\text { (if not surgically } \\
\text { resected) }\end{array}$ \\
\hline
\end{tabular}

\subsection{Topical therapy and wound dressing in DFI}

In general, DFUs with heavy exudates need a dressing that absorbs moisture, whereas dry wounds need topical treatments that add moisture. Topical antimicrobial agents as well as antimicrobial impregnated wound dressings (e.g. those containing sliver and iodine) useful for preventing and treating the mild infections. Antibiotic therapy in DFI impaired by the presence of biofilm. Eradicating the bacteria in a biofilm may require physical removal and is often combined with topical agents; they are hypochlorous acid, cadexomer iodine, and systemic agents such as fluoroquinolones and rifampicin [18]. 


\subsection{Other therapies}

Maggot debridement therapy, antibiotic-impregnated beads, granulocyte colony stimulating factor and hyperbaric oxygen therapy and also the application of negative pressure wound therapy have been used for the diabetic foot infection [19].

\section{Prevention}

The best method to prevent diabetic foot infection is the early detection of neuropathy before its complications. Patients with diabetes should undergo a systemic foot examination at least once a year if the risk for a foot ulcer. Preventive measures are educating the patient about proper foot care, glycemic control, use of prescription footwear, smoking cessation, podiatric care, and evaluation of surgical interventions as indicated [20].

\section{Conclusion}

Diabetic foot infections increase the risk of morbidity, hospitalization, and amputations. Early recognition, classification, diagnosis, and treatment of foot complications are needed to optimize outcomes in patients with diabetes. It is important to accurate classification of DFI to guide the treatment regimens. The infected wound requires proper antibiotic therapy, and the agents and duration of treatment should be predicted based on the severity of the infection. Initial antibiotic therapy should select empirically, and it is based on the presenting clinical features, assessment of infection severity and by knowledge of antibiotic resistance pattern. Clinical failure of appropriate antibiotic therapy occurs due to patient non-adherence, antibiotic resistance, undiagnosed deep abscess or osteomyelitis, or severe tissue ischemia.

\section{Compliance with ethical standards}

\section{Acknowledgments}

The authors are thankful to management of St James medical Academy, Chalakudy, Kerala for providing facilities for the project work.

\section{Disclosure of conflict of interest}

All authors declare that they have no conflict of interest.

\section{References}

[1] Lipsky BA, Bowker JH and Pfeifer MA (2001). Infectious problems of the foot in diabetic patients. In, Eds. The diabetic foot, 6, 467-80.

[2] Reiber GE, Vileikyte L, Boyko EJ, del Aguila M, Smith DG, Lavery LA and Boulton AJ. (1999). Causal pathways for incident lower-extremity ulcers in patients with diabetes from two settings. Diabetes Care, 22, 157-62.

[3] Bagdade JD, Root RK and Bulger RJ. (1974). Impaired leukocyte function in patients with poorly controlled diabetes. Diabetes, 23, 9-15.

[4] Abdulrazak A, Bitar ZI, Al-Shamali AA and Mobasher LA. (2005). Bacteriological study of diabetic foot infections. Diabetes Complications, 19(3), 138-141.

[5] Lipsky BA, Pecoraro RE and Wheat JL. (1990).The diabetic foot: soft tissue and bone infection. Infectious Disease Clinics of North America, 4,409-32.

[6] Sapico FL, Witte JL, Canawati HN, Montgomerie JZ and Bessman AW. (1984). the infected foot of the diabetic patient: quantitative microbiology and analysis of clinical features. Reviews of Infectious Diseases, 6(Suppl 1), $171-6$.

[7] Tentolouris N, Jude EB, Smirnof I, Knowles EA and Boulton AJ. (1999). Methicillin-resistant Staphylococcus aureus: an increasing problem in a diabetic foot clinic. Diabetic Medicine, 16, 767-71.

[8] Lavery LA, Armstrong DG, Wunderlich RP, Mohler MJ, Wendel CS and Lipsky BA. (2006). Risk factors for foot infections in individuals with diabetes. Diabetes Care, 29, 1288-93. 
[9] Lipsky BA, Peters EJ, Senneville E, BerendtAR,Embil JM, Lavery LA and Jeffcoate WJ. (2012). Expert opinion on the management of infections in the diabetic foot. Diabetes/Metabolism Research and Reviews, 28(suppl 1), 163178.

[10] Pittet D, Wyssa B, Herter-Clavel C, Kursteiner K, Vaucher J and Lew PD. (1999). Outcome of diabetic foot infections treated conservatively: a retrospective cohort study with long-term follow-up. Archives of Internal Medicine, 159(8), 851-856.

[11] Palestro CJ, Mehta HH, Patel M, Freeman SJ, Harrington WN, Tomas MB, and Marwin SE.(1998). Marrow versus infection in the Charcot joint: indium-111 leukocyte and technetium-99m sulfur colloid scintigraphy. Journal of Nuclear Medicine, 39, 346-350.

[12] Armstrong DG, Lavery LA and Harkless LB. (1998). Validation of a diabetic wound classification system: the contribution of depth, infection, and ischemia to risk of amputation. Diabetes Care, 21, 855-9.

[13] Lipsky BA. (2004). Medical Treatment of Diabetic Foot Infections. Clinical Infectious Diseases, 39, S104-114.

[14] Tan JS, Friedman NM, Hazelton-Miller C, Flanagan JP and File TM Jr. (1996). Can aggressive treatment of diabetic foot infections reduce the need for above-ankle amputation? Clinical Infectious Diseases, 23(2), 286-291.

[15] Schaper NC, Andros G, Apelqvist J Bakker K, Lammer J, Mills JL, Reekers J, Shearman CP and Hinchliffe RJ. (2012). Diagnosis and treatment of peripheral arterial disease in diabetic patients with a foot ulcer. A progress report of the International Working Group on the Diabetic Foot. Diabetes/Metabolism Research and Reviews, 28, 218224.

[16] Lipsky BA. (2007). Empirical therapy for diabetic foot infections: are there clinical clues to guide antibiotic selection. Clinical Microbiology and Infection, 13, 351-353.

[17] Lipsky BA, Berendt AR, Cornia PB, Pile JC,Peters EJ, Armstrong DG, Deery HG and Embil JM. (2012). Infectious Diseases Society of America clinical practice guideline for the diagnosis and treatment of diabetic foot infections. Clinical Infectious Diseases, 54,132-173.

[18] Percival SL, Finnegan S, Donelli G, Vuotto C, Rimmer S and Lipsky BA.(2016). Antiseptics for treating infected wounds: Efficacy on biofilms and effect of pH. Critical Reviews in Microbiology, 42(2), 293-309.

[19] Krause FG, deVries G, Meakin C, Kalla TP, Younger AS.(2009). Outcome of transmetatarsal amputations in diabetics using antibiotic beads. Foot \& Ankle International, 30, 486-493.

[20] Boulton AJ, Armstrong DG, Albert SF, Frykberg RG, Hellman R, kirkman MS, Lavery LA, Lemaster JW and Mueller MJ. (2008). Comprehensive foot examination and risk assessment: a report of the task force of the foot care interest group of the american diabetes association, with endorsement by the american association of clinical endocrinologists. Diabetes Care, 31(8), 1679-1685.

\section{How to cite this article}

Anette P, Krishna KK, Panayappan L and Leo M. (2018). Diabetic foot infection and its management: A review. GSC Biological and Pharmaceutical Sciences, 4(1), 19-24. 